\title{
EQUILIBRIUM
}

Quarterly Journal of Economics and Economic Policy

2014 VOLUME 9 ISSUE 4, December

p-ISSN 1689-765X, e-ISSN 2353-3293

www.economic-policy.pl

Arnania-Kepuladze, T. (2014). Institutions: Uncertainty in Definition of the Term. A Brief Look at the history: 1890-1930. Equilibrium. Quarterly Journal of Economics and Economic Policy, 9(3), pp. 79102, DOI: http://dx.doi.org/10.12775/EQUIL.2014.026

\author{
Tamila Arnania-Kepuladze*
}

Akaki Tsereteli State University, Georgia

\section{Institutions: Uncertainty in Definition of the Term. A Brief Look at the History: 1890-1930}

JEL Classification: $B 15 ; B 25 ; B 52$

Keywords: institution; behaviour; uncertainty; definition

\begin{abstract}
Despite the fact that the significance of institutional economics is commonly recognized, the uncertainty of basic concepts of institutional economics - institutions - and its investigation sphere is widely mentioned today.

The paper aims to trace the process of evolution in the understanding of the notion of institution, from its spontaneous mentions and pragmatic use of the socalled pre-institutional era to the desire to understand and to define the essence of the institution in the period of early institutionalism.

Based on the analyses of appropriate literature, the paper tries to study how the term "institution" was understood at the three initial historical period of its usage. For this purpose, the first part of the paper analyses how the term "institution" was used at the start by religious figures in VII and XIII centuries and then by thinkers in XVII-XVIII centuries which are considered as a pre-history of the term "institution" wide usage. The second part of the study is focused on the investigation how the term was understood by immediate predecessors of institutional economics - German Historical School, and the third part of the paper investigates scholars-institutionalists' efforts in the intellectual context on the period 18901930.
\end{abstract}

(C) Copyright Institute of Economic Research \& Polish Economic Society Branch in Toruń Date of submission: January 12, 2014; date of acceptance: August 15, 2014

* Contact: tarnania@yahoo.com, Akaki Tsereteli State University, Tamar Mephe 59, 4600, Kutaisi, Georgia 
(...) truth consisteth in the right ordering of names in our affirmations, a man that seeketh precise truth had need to remember what every name he uses stands for, and to place it accordingly.

Thomas Hobbes, 1651, The Leviathan

\section{Introduction}

During last some decade institutional economics is becoming more and more widespread and attractive approach in economic science. This is evidenced by the rapidly rising number of researches dedicated to the development (and critics as well) of institutional economics and its ideas, or using institutional approach of investigation. This is evidenced also by the fact that considerable numbers of the Nobel Prize winners in economics are representatives of institutional economic theory or to any extent connected to institutionalism and institutions. Suffice it to recall names such as Ronald H. Coase (Nobel in 1991), Robert W. Fogel and Douglass C. North (Nobel in 1993), Elinor Ostrom and Oliver E. Williamson (Nobel in 2009), etc. Today no discussion of methodology in economics is complete without a mention of institutional economics (Blaug, 1990, p. 708). As Malcolm Rutherford has mentioned: "institutionalism ... became a force to be reckoned" (Rutherford, 2008, p. 1).

The importance of institutional approach was recognized even by the representatives of the economic school, against which the institutionalism was initially oriented. Thus, the founder of the neoclassical school of economics Alfred Marshal (1990) mentioned that institutional structure exerts an important influence on behavior.

Despite common recognizing of the theoretical and practical significance of institutional economics, both the field of investigation of institutional economics and its basic category - institution remain uncertain. Up to this day, the concept of institutions seems quite blurred and reflects a wide diversity of researchers' viewpoints toward its definition. The terms "institution", "institutional analysis", "institutional approach" are used with vast variety of understanding and the field of investigation of institutional economics is not defined enough clear. As Hollingsworth emphasized "there is no consensus as to what is meant by institution and institutional analysis. These terms ... are used with different conceptualizations, and the scholars who use them share little common ground" (Hollingsworth, 2000, p. 598). J. R. Searle (2005) supports the opinion concerning the uncertainty regarding to what institutions exactly are, and claims that the ontology of 
this term still is not clear. Similar opinions were repeatedly given by other authors (Hodgson, 2006; Hamilton, 1962; Williamson, 2000; Leftwich, 2006). Arrow (Arrow, 1970, p. 224) took a step further and emphasized that "since research in this area is still at its early stage, undue exactness must be avoided". After 1970th the situation changed slightly.

Undiminishing academic interest toward institutional economics is based on a compounding of the increasing awareness of the significance and practical usability of the institutional approach and the remaining uncertainty of its basic concepts.

The paradox is that being called to reduce uncertainty, the institutions existing from the beginning of the concept remain to be uncertain. In such conditions "it is tempting to try to secure some precision in the formulating a definition for so basic a concept as the "institution" (Furubotn \& Richter, 2007, p. 6).

How the understanding of the concept of "institutions" has varied through the time, what influence the ambiguousness of its definitions, why the term still remains to be unclear, what caused its misunderstanding - these are the questions evoking an undiminishing interest of investigators. In this paper I will concentrate my attention on the process determining how the term "institution" was understood at the early stage of its existence and how its investigation sphere was defined by founders of institutional economics and their predecessors.

\section{Methodology of the research}

The paper is largely based on the analysis of appropriate scientific literature regarding how the term "institution" was understood in the period before and early stage of its wide recognition. The study proceeds from the assumption that uncertainty in definition of the term "institution" could be to a certain extent predetermined by ambiguousness in its usage in a period antecedent to the rise of institutional economics.

Therefore, the first part of the paper analyses how the term "institution" was used by religious figures in the 7th and the 8th century and by thinkers in the 17th and 18th century. The second part of the study is focused on the investigation how the term was understood and used by immediate predecessors of institutional economics - German Historical School, and the third part of the paper investigates scholars-institutionalists' efforts in the intellectual context on the period 1890-1930. 


\section{Pre-history of Uncertainty}

As Geoffrey M. Hodgson (2006) mentions, the term "institution" has a very long history, and it is dated back to at least 1725 and connected with Giambattista Vico's work „The New Science“ ("Scienza Nuova“). But one could find earlier applications of the concept "institution", which goes back at least to the first half of the seventh century, and is connected with an English monk at the monastery of Saint Peter at Monkwearmouth Saint (Venerable) Bede (672-735). In his most famous work, "The Ecclesiastical History of the English People" ("Historia ecclesiastica gentis Anglorum"), which was completed in 731, Bede mentioned an "ancient institution of the fathers" or "antiqua patrum institutio invenit". He distinguished "good institutions" which have to be to imitated and "imperfect institution" which have to be renounced. As a "doctor ecclesiae", Bede paid essential attention to Catholic institutions (institutione catholica), apostolical institution, monastic institution, ecclesiastical institution, etc... Bede discerned the characteristics of institutions such as their being rigid, and spoke about benefit of some institutions and possibility of their admission.

Later, the term institution was used by Thomas Aquinas (1225-1274). Thomas Aquinas considered institutions in religion context and spoke about institution of God, institution of the Church. But T. Aquinas extended the concept of institutions on other things, particularly, he differentiated between wholesome institution, institutions of human law, and institution of natural law. Thomas Aquinas connected the existence of institutions with public welfare and considered a "defective" and "less defective institutions" in the context of public welfare and common good. In particular, he viewed "the institution of buying and selling" as advantage for both parties of a transaction, and therefore as tied with public welfare (Aquinas, 1256, p. 307). Thomas Aquinas considered the equivalence exchange of goods as a contract between sellers and buyers.

In Aquinas's understanding, institutions are created or invented by God and by human. He considered marriage as a divine institution and recognized God as the author of the institution of marriage (Aquinas, 1256, p. 307). In his opinion, there are positive institutions, which include naturallaw-based private property. According to Thomas Aquinas, the last mentioned one, i.e. private property, "is not against natural law, but is an institution supplementary to natural law invented by human reason" (Aquinas 1274, p. 55).

In the middle of the 17th century English philosopher Thomas Hobbes (1588-1679) displayed a comparatively more systematic understanding and using of the concept of "institutions". In his famous work "The Leviathan" (1651) he is concentrated on the formation of basic political institutions. 
Thomas Hobbes considered political institutions as a result of a social contract between the people who lived in a society without any regulations and cause harm to each other in an interaction process and "hurt themselves by their own impetuous desires" (Hobbes, 1660, Chapter XXX). According to Hobbes, men had realized that they would all live better off if there are "valid covenants" in the society and compulsion "not breaking, but keeping of covenant" (Hobbes, 1660, Chapter XV) i.e. through bringing into reality a certain clearness. The "covenants" act through a law with the purpose to achieve the justice and adherence to the right. Just rights are the key pillar basic for the social contract. Hobbes defined "contract" as "the mutual transferring of rights" (Hobbes, 1660, Chapter XIV). But people always look after their own interests. Therefore, people are not inclined to voluntary follow the covenants and they observe the law only under the pain of punishment.

It has to be mentioned that Thomas Hobbes homologated the laws of the State ("laws of a Commonwealth") with "the laws of the game" and argued that "whatsoever the gamesters all agree on is injustice to none of them" (Hobbes, 1660, Chapter XXX). In Hobbes' understanding, the "laws", should it be the laws of a state or the laws of the game, are the "authorized rules". Such a standpoint to a certain level corresponds with the viewpoints by W. N. Hohfeld (1913), J. R. Commoms' (1924), D. North's (2006) etc.

With respect to Giambattista (Giovan Battista) Vico (1668-1744), he recognized different types of institutions such as religions, language, lands, nuptials, the name of clans or families, commands, magistrates, laws (Vico, 1948, pp. 210-211) and, like Thomas Aquinas, had distinguished the divine and human institutions. Giambattista Vico described the development process of "the world of civil society" and reconsidered the role of the religion ("divine providence") in this process when the civil society is impacted by political and human actions.

Giambattista Vico proposed the theory of the progressive development of humanity through the cyclic development of individual nations. He distinguished three periods ("ages") in the humanity development - the divine age, the heroic age, and the human age. According to G. Vico, the different periods which the world has passed up to their time, are tied with particular divine and human institutions. G. Vico argued that each stage of society development has its own institutions. Thus, G. Vico denoted "oldest institutions" or "divine institutions" when "everything was commanded ... by auspices and oracles", the heroic epoch personified feudal monarchic institutions while the human age recognized the equality of all men nature (Vico, 1948, p. 18). 
Proceeding from the assumption that the world of civil society has certainly been made by men and that human (including mental) capabilities are limited, Giambattista Vico gave reason for the necessity of existence of certain institutions. The institutions are based on the universal and eternal principles on which all men have always agreed and on which all nations were founded and which still prevail (Vico, 1948, p. 86). Among different types of institutions (e.g., institutions of burial, institutions of matrimony), G. Vico specially emphasized three of them: religion, marriage, and burial, and emphasized their influence on all nations. He attached such a great importance to these institutions that he called them "three first principles of the Science" (Vico, 1948, p. 86).

The concept of an institution could be found in the first works on political economy. Almost together with Giambattista Vico, the term "institution" was used by David Hume (1711-1776). One of the ancestors of Institutional Economic School - John R. Commons - highly estimated David Hume and argued that "Institutional economics goes back to Hume" (Commons, 1931). If T. Hobbes recognized the intentional, deliberate character of the institutions and estimated them as a result of covenant between the humans, David Hume evaluated institutions as byproduct of human social interaction. He emphasized the spontaneous character of framing of institutions when people "establish government, as a new invention to attain their ends, and preserve the old, or procure new advantages", to protect and secure oneself (Hume, 1739, Section IX).

In his "A Treatise of Human Nature" (1738) David Hume considered institutions as a deliberated necessity to restrain "natural appetites" of men to observe the fundamental laws of nature. According to his opinion, the institution of government is established for the sake of the execution of the rules of justice and civil duties. Here Hume put the institutions in the direct relations with rules and necessity of their appliance. Exact observance of the laws, rules and duties he evaluated as "an effect of the institution of government" (Hume, 1739, Section IX).

In David Hume's understanding, the connection of institutions and limitations could be found. Hume noted that security and protection could not be attained in a "perfectly free and independent" environment and institutions limit men's action. The men agree with the limitations of their action if they expect some benefits. But, if instead of advantages of the government institution existence the men experience arrangements which "turn entirely to the advantage of others, without any view of bettering their own condition", the men "return to that state of liberty, which preceded the institution of government". By such viewpoint, David Hume has pointed the random character of the men-government relations and defined the institu- 
tion of government as a conditional contract which exists as long as the institution corresponds the interest of human.

David Hume's ideas to a certain level made an impact on and, in turn, were influenced by Adam Smith's thinking. Acquainted in 1750, David Hume and Adam Smith had established so-called intellectual alliance which has played an important role at time of Scottish Enlightenment development. The affinity of their views could be retraced in their works in philosophy, history, economics, politics etc.

Adam Smith (1723-1790) evaluated institutions proceeding from his own perception of the nature of human and from idea of "homo economicus". According to Adam Smith, institutions are an unintended result of the actions of a multitude of individuals who pursue their own interests. He has recognized and considered different types of institutions such as human institution, political institutions, public institutions, commercial institutions, institutions for education, people institutions or the institutions for the instruction of people of all ages and which are chiefly destined for religious instruction (Smith, 1843, p. 273).

Adam Smith's attitude toward institutions was impacted by the ambiguity of his methodology and his estimation of institutions was not singlevalued. He saw regulatory beginning of institutions and, as a typical representative of classical political economy and advocator of laisser-faire, expressed a negative attitude towards them. Adam Smith recognized "bounty", "taxes", "duties" as "human institutions" and argued that the establishment of the institutions promote the monopoly of the home market and "raised the real value of many different sorts of manufactured goods" (Smith, 1843, p. 16).

Speaking about market price fluctuation under the influence of plenty or/and scarcity, Adam Smith denied the regulatory role of "any... human institution" (Smith, 1843 p.11). He viewed the fluctuation of the value of silver as a result of political institutions (Smith, 1843, pp.12-13) that has "very great" market and social consequence. According to Adam Smith's opinion, political institutions aggravate the disadvantages of countries (Smith, 1843, p. 13). But on the other hand, speaking about mercantilists economic policy and arguing against carrying out trade encouragement, Adam Smith recognized that "the institution itself seems reasonable enough" (Smith, 1843, p. 9) in the context of targeted goals and had expressed the opinion about necessity of some "particular institutions" although he tied their existence with "extraordinary expense" (Smith, 1843, p. 223). Adam Smith fond the importance of different kinds of institutions. For A. Smith it was incontestable that "institutions derived their origin either from irresistible necessity, or from clear and evident utility" (Smith, 1843 , p. 60) and public institutions are "necessary for the defense of the 
society, and for the administration of justice" while commerce institutions for facilitating the commerce of the society (Smith, 1843, p. 214).

According to Adam Smith, public institutions “...can never be for the interest of any individual, or small number of individuals (Smith, 1843, pp. 184-185). He argued that institutions are necessary "for promoting the instruction of the people". Smith recognized the heterogeneity and variability of institutions. He pointed that some institutions don't need external intervention for maintaining their own effectiveness, while others once established and having realized their own goals, constantly fall into total negligence if they were not be supported by government to maintain them in the most perfect vigor" (Smith, 1843, pp. 271-272).

A prominent representative of classical liberal political theory, English sociologist, philosopher and biologist Herbert Spencer (1820-1903) in his numerous works and especially in "The Principles of Sociology" (1876, 1885) as well as in "Essays: Scientific, Political and Speculative" (1891), has distinguished a very wide range of institutions. Spencer considered institutions as a fact and did not argue about the necessity of its existence.

According to Spencer, the political institutions were established as a result of conflicts and wars, as a result of replacement of intergroup confrontations in the between-groups standoff; the ceremonial institutions were designed to regulate the everyday life of the men and their behavior through setting etiquette, rituals and habits; the domestic institutions are promoted to solve the problems of families, education, marriage; the religious and ecclesiastical institutions incorporated temples, churches, parochial schools, and religious traditions; the professional or economic institutions integrate the groups of men by their professional activity, while industrial institution are based on the enacted laws support the production structure of society and their future "is bound up with the future of social institutions at large" (Spencer, 1898, p. 592).

Herbert Spencer also mentioned the institutions of chivalry, royal institutions, pagan institutions, social institutions, municipal institutions, popular institutions, educational institutions, teaching institutions, military institutions, feudal institutions, judicial institutions, primitive institutions which include coercive institutions, monarchical institutions, republican institutions, civil institutions, etc. Spencer has analyzed whether institutions meet the needs of a society. He recognized the adaptive character of institutions and their changeability under the influence of internal environment and argued that the "institutions need remodeling with a frequency proportionate to the rapidity of the change" (Spencer, 1898, p. 101). The bases of adequate, socially acceptable institutions are the justice, respect and faith of men. He believed that institutions "should succour the man", otherwise "the day of their dissolution is not far off" (Spencer, 1891, p. 47). The defects, 
imperfections of institutions produce disastrous mismanagement (Spencer, 1891, p. 286) and "the institution loses its prestige, and dwindles away" (Spencer, 1891, p. 288). Discussing the problem of social equilibration, Herbert Spencer indicated of an essential importance of the establishment of governmental institutions, which fall into harmony with the desires of the people (Spencer, 1898, p. 459). Through social selections, the ineffective institutions are substituted by effective ones. He denied the invariableness of institutions and argued that "no institution is sacred, no belief above criticism" (Spencer, 1891, p. 32).

Herbert Spencer tightly connected the existence of institutions with their regulative function and social circumstance of society when "less stringent institutions would entail social confusion and its far more severe evils" (Spencer, 1891, p. 160). Therefore, the dilemma of "good" and "bad" institutions was very significant to Herbert Spencer: good institutions as well as good laws produce to their societies benefits (Spencer, 1891, p. 203).

In Spencer's viewpoints elements of informal relations and informal institutions could be found. In particular, he spoke about "developed a highly complex aggregation of customs, manners, and temporary fashions, enforced by society at large". Such aggregation has to "serve to control those minor transactions between man and man which are not regulated by civil and religious law" (Spencer, 1891, p. 247).

Consequently, Herbert Spencer considered institutions as a way of human co-existence, as a co-organization of men activity with the purpose to satisfy the common needs of a society. For Herbert Spencer, as well as for his predecessors, institutions were socially-efficient mechanism which are meant for regulation of different sides of life and first of all for the coordination humans' collaborative activity. At that, the way of institutions formation was not under consideration.

Those viewpoints and such an approach had played an essential role in the shaping of institutions understanding and largely predetermined the future development of their perception. The further evolution of the concept of institutions was given by German Historical School, which in its turn had a significant bearing on the institutions understanding and on the institutional economics as a whole.

\section{Infancy: German Historical School and Institutional Thinking}

The German Historical School and its major scholars such as Gustav von Schmoller, Max Weber and Werner Sombart are recognized as one of the origins, the historical roots of institutionalism. 
A forefather of the German Historical School Friedrich List (1789-1846) used widely the term institutions. In his famous work „The National System of Political Economy" (1841). He considered institutions in the historical and country perspective, and analyzed the role various institutions in ancient Rome, in Italy, France and in other countries (List, 1909).

Recognizing the different types of institutions such as freedom and civic institutions, internal institutions, political and public institutions, social institutions, crippled and good institutions, credit institutions, banks and money institutions etc., Friedrich List highly evaluated the role and importance of the impact of the institutions on the various aspect of social, economic, and political side of society. Friedrich List saw the role of public institutions in the promoting of the religious character, morality and intelligence, security for a person and for property, freedom and justice. Of course, he recognized that institutions do not produce values immediately, but he also recognized the fact that institutions produce productive powers and the ability to obtain wealth.

Friedrich List regarded institutions, especially free institutions, as well as social, municipal, and political institutions as one of the most important source of a nation's economic progress, for a high degree of prosperity and civilization in the cities, for the promotion of agriculture and for the development of arts and manufacture (List, 1909, p. 10, 92, 112, 118, 181, 202). But, on the other hand, he recognized that the want of political institutions could greatly hinder industrial and commercial progress (List, 1909, p. 76).

Friedrich List also put the well-being of each man and progress of entrepreneurship under the influence of institutions. So, he argued that the wealth of individuals and the powers of production are growing in proportion to the degree of perfection of political and social institutions. Friedrich List highly appraised the institution of an aristocracy which was more judiciously designed in England and which secured individual independence, dignity, and stability, parliamentary training and position, etc. for Britain nobility. At the same time, Friedrich List directed an attention to an inverse fact that the industrial independence, internal prosperity and well-being of a nation positively influence its institutions and their perfection.

Does not setting as a goal to understand the essence of institutions, Friedrich List regarded as institution different subjects and phenomenon such as factory, educational establishments, industrial exhibitions, offers of prizes, transport improvements, patent laws, customs duties etc. (List, 1909, pp.13, 247). Friedrich List distinguished the institutions regarding their quality and noted the good institutions and defective institutions. Namely good or efficient institutions promote the well-being of a nation and its individual subjects, while defective institutions lead to incapacity of vari- 
ous spheres of human life, to limitation of civil liberty and of security of justice and a society as a whole.

The leader of Younger German Historical School of economics - Gustav v. Schmoller (1838-1917) - is acknowledged as the father of American Institutional Economics (Schumpeter, 1926, p. 355). Alike the institutional economics, German Historical School was established as an opposition to self-interest-based neoclassical economics. According to this issue, Schmoller at the early turn of XX century wrote: "The old (classical) economics, submerged in the analysis of prices and the phenomena of circulation, represents the attempt to provide an economic physiology of the juices of the body without anatomy" (Schmoller, 1900, p. 64).

Schmoller considered different types of institutions such as economic institutions, human institutions, social institutions, agrarian institutions, public institutions, traditional institution etc. But unlike his predecessors, Schmoller on repeated occasions came back to attempt to define what the institutions are. According to his perception, the institutions are "a part order for community life which serves specific purposes and which has the capacity to undergo further evolution independently. It offers a firm basis for shaping social actions over long periods of time; as for example property, slavery, serfhood, marriage, guardianship, market system, coinage system, freedom of trade. (Schmoller, 1990, p. 61). Apart from common definition of institutions, G. Schmoller tried to define the different types of institutions. So, he has defined the economic institutions as "complexes of rules of morals and right" which coordinate the work and life of humans and harmonized their activities with "ideal conceptions of justice", as "a product of "feelings and thought, of human actions, human customs and human Laws" (Schmoller, 1881).

Schmoller defined "institutions as not only in the narrow sense of formal organizations, but in the broad sense of socially habituated behavior " (The Historicity of Economics..., 2002, p. 4) and saw in institutions a direct interdependence with human actions. Gustav v. Schmoller endorsed the idea of necessity of the existence of institutions and their continuity through the historical development of society. He wrote: "institutions must never disappear in form and substance, that nations can never create anything wholly new, but must always build on what exists" (Schmoller, 1881). According to Schmoller, a lasting continuity of institutions provides inheritance of "wisdom and justice" which is contained in traditional institutions. At the same time, Gustav v. Schmoller does not see the direct invariability of the institutions and their priority over the history. In the G. Schmoller's interpretation, the result of functioning of each institution has to be tested concerning its origin, conceptions of justice and necessity of existence for every period of time. 
In such a manner, Gustav v. Schmoller considered institutions in the historical context and recognized both as variability of institutions through time as well their succession, inheritance of main and more important characteristics. Underlining the vast role of institutions, Schmoller considered them as a source of social differentiation, "social classification". In this context, he wrote that "the position of social classes in general is determined by the institutions" (Schmoller, 1881).

Gustav v. Schmoller developed a wide understanding of institutions and considered institutions and organization not only from the technical position, but also in the psychological, moral, and ethical context. He believed that "... economic institutions should be derived from psychological power in general, from sentiment and instinct, from ethical ideas" (Schmoller, 1911, p. 448).

Another representative of Younger German Historical School of economics - Karl Bucher (1847-1930) -understood the essence of the term "institution" ambiguously. In his perception, the institutions are particular mechanism for doing certain actions. For example, he emphasized the institutions for extortion, the institutions of the system of gifts, institutions for system of bribery, etc. (Bucher, 1991, p. 80).

At the same time, along with discussing about the functional role of municipality and State institutions, he has viewed institutions as organizations, and pointed to the state institutions of educations such as monasteries, municipal and cathedral schools, technical schools, asylums for the blind, institutions for the deaf and dumb, prison and barracks, postal institutions (Bucher, 1991, p. 146, 190, 242), etc.

On the other hand, Karl Bucher combined those perceptions and he simultaneously evaluated one and the same institution as an organization and as a specific mechanism. So, he viewed the factory as organizations and as a mechanism for effective utilization of labour. He mentioned that in order to effectively use labour, it is necessary to take "a peculiar road" (Bucher, 1991, p. 174). Karl Bucher regarded institutions in the cultural context and argued that in case of migration "the stranger has to adapt himself to his environment ... the political, religious and social institutions of his new abode" (Bucher, 1991, p. 366).

German economist and educator Georg Friedrich Knapp (1842-1926) developed his own perception of institutions in his famous book "The State Theory of money" (1905). The English translation of the book was called by his contemporary - Ralph Hawtrey - an "event" of economic science which "has deeply influenced German thought on monetary theory" (Hawtrey, 1925, p. 251). 
Investigating the "theory or philosophy" of banking, currency, and money, Knapp tightly connected the term "institutions" with issues of currency circulation. He views institutions as organizations, as separate subject of activity and, proceeding from his investigation sphere, considered a bank as institution and described the particularities of its functioning. Georg F. Knapp spoke about "a private institution" and meant bank by the term, and the "general exchange-commodity is institution of social intercourse" (Knapp, 1924, p. 3, 192 etc.).

He argued that in "any society ... a custom gradually recognized by law" (Knapp, 1924, p. 3). So, as early as 1905, Georg F. Knapp pointed, in the parlance of our time, the possibility of transition of informal institutions into formal institutions.

The term "institution" was widely used by the followers of Youngest Historical School of Germany and its leader Werner Sombart (1863-1941). Werner Sombart recognized the economic and social institutions, free institutions, humanitarian institutions, proletarian institution, trade-union or the workers' syndicate and co-operative society, credit institution, legal institutions, commercial institutions (Sombart, 1909, p. 12, 102, 125, 140, 146; Sombart, 2001, p. 47) etc. By free institutions he understood the parliamentary system and argued that free institutions comply with the interests of the middle class while trade-union is "a proletarian institution in the best sense" (Sombart, 1909, p. 26, 102). Sombart introduced the trade union and the co-operative society as two backbone institutions for the labour movement (Sombart, 1909, p. 146). He recognized that institutions are "the embodiment of a certain spirit" (Sombart, 2001, p. 83) and they fell within the scope of the regulations. At that, in case of legal institution W. Sombart has identified fundamental regulations which are less changeable from age to age and those which vary with the progress of society (Sombart, 2001, p. 93). Werner Sombart considered institutions in the context of class interests, "social spirit" and contributed institutions expressly political overtone.

The term "institutions" was used by the representatives of German Historical School of Economics and their predecessors as supportive, concomitant for investigation of various economic issues. They understood institutions and organizations as very similar concepts and often replaced one term by other. At the same time, in continuation of Friedrich List, the leader of Younger German Historical School of economics Gustav v. Schmoller and after him other representatives of Historical School recognized the importance of institutions in the formation of economic actors' behavior, and considered economic behavior through the cultural background. By admission of the fact that institutions are changeable through the time, the Historical School of Economics predated the idea of evolutionary character of institutions. Economists of German Historical School in a great deal pre- 
empted most of ideas of American Institutional Economics and recognized the importance of tradition, habit, custom, law, moral etc.

\section{Childhood: The Old Institutionalism}

Initially, like German Historical School, the institutional economics rose and developed as an opposition to the classical economic theory. In particular, the founder of the institutional school of political economy and the leader of the institutional economics Thorstein Veblen (1857-1924) came to the idea of institutions through the criticism of classical economists' "archaic habit of thought" (Veblen, 1898). Being under the influence of zoologist and philosopher C. Lloyd Morgan, and therefore being the adherent of Darwinian's evolutionary theory, Veblen evaluated his contemporary economic sciences as an inconsistent to its time and aspired to modify economics into evolutionary science. According to Veblen, the evolutionary science is a theory of a process. Veblen considered the direct interconnection between evolutionary science, evolutionary economics and institutions, and he "made institutions the objects of selection in socio-economic evolution" (Hodgson, 1998, p. 420). He wrote in 1898: "evolutionary economics must be the theory of ... a cumulative sequence of economic institutions stated in terms of the process itself" (Veblen, 1898). Therefore, Veblen presented the institutions as an integral and dynamical part of evolutionary economics. For Veblen, economics is evolutionary science which treated genetically into a progress of institutions. Veblen's definitions of institutions are not univocal. He saw the connection between institutions and habits and defined institutions as "habits of thought", which turned out to be fittest in process of a natural selection (Veblen, 1899, p. 188). He argued that "any institution is a product of habit or, perhaps more accurately, it is a body of habits of thought bearing on a given line of conduct, which prevails with such generality and uniformity throughout the group as to have become a matter of common sense" (Veblen, 1917, p. 92). Veblen viewed institutions as a "special method of life and of human relations", as a habitual method of human community existence in connection with their material live environment. Veblen considered institutions as externalization of a methods adopted in the past, as "habitual methods of carrying on the life of the community in contact with the material environment in which it lives" (Veblen, 1899, p.193). Veblen argued that during the historical development through institutional changes the habits and the exigencies of life have greatly changed (Veblen, 1917, p. 49).

In spite of Veblen's scientific outlooks not always expressed congenerical essence, his attitude toward evolutionary changes remained central for 
him. Just from position of change and development, the institutions were regarded by Veblen. He argued that during the historical development all (human) institutions are susceptible of improvement and undergoing changes. The changeability of institution "results in supersession and displacement" (Veblen, 2001, p. 31). Veblen represented every institution as a product of habits and customs (Veblen, 1917, p. 92). Herewith, the approach to institutions from the position of habits remained crucial for Veblen. He aspired to study the economic phenomenon as a particular set of habits and customs, which having been set up once has inertia and authority. The habits and customs were embodied in the institutions and defined the subsequent economic and social relations and development. In such a way, Veblen represented institutions as a set of circumstances depended and changeable social customs, as embodiment of certain habits of behavior, as a way of thinking and life, passed down from generation to generation.

Not having a decisive perception about the concept of institution, Veblen considered different types of institutions such as "social institutions", "economic institutions" (Veblen, 1898; 1899) "human institutions" (Veblen, 1899; 2001, 1904), "governmental institutions" (Veblen, 1917), etc. Particular attention was paid by Veblen to governmental institutions. At the beginning of 20th century, Thorsten Veblen studied the problem of nature and derivation of governmental institutions. He considered material circumstances which destined the beginnings of governmental institutions, the causes which destined the rate and directions of their development (growth and mutation) and influence the peace, material welfare or the cultural fortunes (Veblen, 1917).

According to Veblen, the economic institutions are corresponding to the activities of business and industry. The normalized accounts of the beginnings of barter, money, wages are considered by Veblen as economic institutions (Veblen 1898; 1904, p. 70, 342). The ownership is also evaluated by Veblen as institution. Discussing the eventual problem of moving to a "new and more practicable system of industrial production and distribution", Veblen concentrated his attention on the possibility of disallowance of absentee ownership and considered the process as "disestablishment of an institution" (Veblen, 2001, p. 96). Similarly, Veblen defined credit and named him as one of the timeworn institutions, "that are due to suffer obsolescence by improvement" (Veblen, 2001, p. 32). Such a wide definition, of course, "leaves the essential features of institutionalism vague and uncertain" (Harris, 1932, p. 732).

Thorstein Veblen recognized that the scope and content of institutional economic school is unlimited and tried to develop criteria and norms of institutional economics. For Veblen, economic institutions are a "range of 
conventionalities and methods of life", a "convenient caption" which most consistently expressed economic interest. The economic interest is put by Veblen at the base of economic institutions. Defining widely the category of economic institutions, Veblen argued that inasmuch as economic interest impacts on the all sides of human life and cultural structure, all institutions (social institutions, human institutions, governmental institutions etc.) could be viewed as economic institutions (Veblen, 1898). Therefore, solely an economic interest was interposed by Veblen as "most immediately and consistently finds expression, and which most immediately and with the least limitation are of an economic bearing" (Veblen, 1898). Veblen followed up the connection between institutions existence and business necessities. As far as institutions are changeable, they are susceptible of improvement and these improvements, according to Veblen, are "for the good of business, more particularly for the profit of big business" (Veblen, 2001, p. 31).

Veblen considered evolution of institutions as a process of substitution, replacement of "old", "outworn institutions" by new institutions (Veblen; 1917, p. 9, p. 49; Veblen; 1904). Veblen built his own approach towards a human behavior. Contrary to classical economic school with its theory of rational choice, Veblen considered human behavior as institutionallydepended, based on the instincts, habits and customs.

Slightly over three decades later, after the publication of Veblen's "Why is Economics Not an Evolutionary Science", unduly wide interpretation of institutions allowed Harris to estimate Veblen's institutionalism as "equivalent to economic determinism" (Harris, 1932, p. 725). Understanding Veblen's position, Harris took a stand in favor of it. Harris recognized that such widening of institutional economics scope promote to involve "all aspects of group organization and effort" (Harris, 1932, p. 725). About hundred years later G.M. Hodgson mentioned that for Veblen "... explanations of socio-economic evolution must involve individual agents as well as institutions and structures" (Hodgson, 1998, p. 419).

Veblen does not create a systematical study of institutions and does not leave more or less reasonable definition of institutions. As we see, the term "institution" had been defined by Thorstein Veblen not quite clearly and his perceptions regarding institutions and institutional analysis was rather limited. Being under the influence of evolutionary theory and looking upon institutions as a modification process, Veblen considered among institutions the instincts, habits and customs as well as economic categories which could be changed. Nevertheless "Veblen had a deeper understanding of theoretical and philosophical tenets that could serve as a possible foundation for institutional economics" 
Among the representatives of the so-called Old Institutionalism, John R. Commons (1862-1945) is recognized as the most important figure in terms of the development of modern institutional economics (Furubotn \& Richter, 2007, p. 34). The problem of uncertainty in a definition of essence of main concept and studying field for the institutional economics was still pointed to by John Commons at the beginning of the third decade of XX century (see: Commons, 1932, p. 648).

John R. Commons developed his own understanding of an institution in his article "Institutional Economics", published in 1931 and then in the same-name book published in 1934. If for T. Veblen the institutions are a widely prevalent habit of thought, John R. Commons saw the mediated interrelation of institutions with collective and individual actions which are exercised through certain operations, such as control, liberation and expansion. Consequently, he defined an institution "as collective action in control, liberation and expansion of individual action" (Commons, 1931). At that, John R. Commons distinguished two margins of collective action where the lower bound is an unorganized custom and the upper bound are the organized activities of the enterprise which act on the principle of control, on the bases of individual actions. Collective actions constitute the "working rules" which are "appropriate to indicate the universal principle of cause, effect or purpose, common to all collective action " and predetermine "what individuals can, must, or may, do or not do" (Commons, 1931).

Through evaluation of the past experience of institutionalism, John R. Commons distinguished various approaches toward definitions of institutions and institutional economics and economic theory as a whole and gave them his own interpretations. Thus, he argued that institutional economics identified itself with any opposition to classical economics with its statics, individualism, laissez faire and equilibrium. John R. Commons endorsed the idea of "the transition from the classical and hedonic schools to the institutional schools of economic thinking" which have to be done through a change in the ultimate unit of economic analyses: if the theory of classic and hedonic economists is based on the relation of man to nature, on the study of the smallest economic units - a commodity produced by labor, then the cornerstone of institutional economics analyses is a relation of man to man and the smallest unit of study are transactions and their participants (Commons, 1931).

In spite of the fact that, as it Mark Blaug argued (Blaug, 1990, p. 708), the critics of orthodoxy had no alternative construction to offer, and the possible exception is the American Institutionalists, John R. Commons' attitude toward classical economics, its methods and the sphere of investigations was not simple. 
As an institutionalist John R. Commons was in opposition to classical economics, but he did not agree that institutional economics have to separate itself from discoveries and insight of the classical economics as well as psychological economics. More than that, he proceeded from opinion that institutional economics has to comprise all of inconsistent of the various schools and not be limited by descriptive approach to the analyses of economic phenomenon. Commons mentioned that institutional economics is not divorced from the theories of classical and psychological schools of economics and recognized the principles of scarcity, efficiency, futurity and limiting factors which were derived from the older schools as a possible and acceptable basis of institutional analysis. But John R. Commons flatly stated that these principles could not be taken in their pure form, they have to be correlated under the institutional understanding and built "under the modern notions of working rules of collective action controlling, liberating and expanding individual action" because in Commons' understanding in opposite to classical and hedonic theories institutional economics is "legal control of commodities and labor" (Commons, 1931).

Like his predecessors, John R. Commons considered various types of institutions. Commons homologated the corporations and the industrial institutions. He wrote that "Many steel corporations and other industrial institutions have instituted in their plans systems of collective bargaining" (Commons, 1921, p. 346). Among institutions John R. Commons mentioned language, customs, laws, and property rights (Commons, 1907, p. 98). Different types of institutions fall under John R. Commons' considerations. So, as a specific kind of a historical institution, he viewed capital which constitutes the ownership of social capital, and the ownership of private capital. Social capital creates utilities, private capital distributes utilities" (Commons, 1893, p. 100).

John R. Commons emphasized the importance of free institutions. Unlike of his predecessors who also mentioned the significant role of free institutions, John R. Commons gave his own understanding of this kind of institution. He tightly connected the free institutions with the sustention of human rights and maintenance human liberties (Commons, 1921, p. 575).

Like Werner Sombart, John R. Commons mentioned the particular "spirit of the institution". But, unlike Werner Sombart, he pays more attention to this "spirit". Under the "spirit" of the institution he probably meant character, nature of every institution. Thus, the nature of free and democratic institutions are dependent upon freedom of speech, of the press, and of assemblage and association and are inimical to human progress and democracy" , the nature of political institutions are compulsory arbitration and prohibition of strikes (Commons, 1921, pp. 571, 575, 820), insuring the adequate security, support, and dignity (Commons, 1896, p. 166), while the 
nature of autocratic institutions are autocratic control and menace to civilization, and he supposed that overthrowing and supplantation of all autocratic institutions leads to full measure of freedom and justice "between man and man and nation and nation" (Commons, 1921, p. 563). The "spirit" of private property institution does not include the promoting equality of opportunity or financial independence or suppose desirability of leveling inequalities of fortune or public welfare. For John R. Commons is clear that the necessary result of the institution of private property is inequality (Commons, 1921, p. 646), that through the institution of private property the government gives certain power to individuals and thereby creates artificial monopoly privileges (Commons, 1893, p. 15). The institution of mutual insurance promote the benefit systems (Commons, 1921, p. 73), social and legal institutions create a framework, an environment for the cooperations of individuals and classes and the fundamental nature of the representative institutions are their adaptability to the exigencies of modern time (Commons, 1896, pp. 9, 165).

Recognizing the ambiguity of institution's nature or a "spirit of the institution", John R. Commons believed that it is possible to influence the specific traits of institutions and to put them into necessary shapes. The changing attitude towards certain aspects of human life and the development of the society leads to changes in institutions. Among various types of institutions John R. Commons recognized two fundamental institutions of society - the State and the family. Arguing against classical political economy with its "homo economicus" and laissez faire principle, John R. Commons saw in institutions, and first of all in State and the family, "the only means whereby refractory, obstructive, and selfishly interested elements of society may be brought into line with social progress" (Commons, 1894, p. 22).

By the negation of the descriptive method of investigation, John R. Commons referred primarily to so-called "economic behavior" as much as to Commons the institutional economics first of all is "behavioristic, and the behavior in question is none other than the behavior of individuals while participating in transactions, institutional economics must make an analysis of the economic behavior of individuals" (Commons, 1931). The economic behavior is based on the expectations to follow the "working rules" and on the choosing (voluntary or involuntary) between alternatives. An involuntary choice could be imposed by another individual or by collective action which are corresponding to working rules.

John R. Commons recognized a certain capacity of natural selection of the social and legal institutions but he was not so judgmental regarding the acceptability of biologically-genetically-programmed and instinct-habitbased Darwinian evolutionary theory in explanation of human behavior and thereby changeability of institutions. The idea that the alteration of institu- 
tions can be done by society was more allowable for him. According to John R. Commons, institutions consist of two elements: "raw material" and "tools". The "raw material" includes race and heredity, while the "tools" include education and environ (Commons, 1907, p. 4).

John R. Commons recognized the historical essence of institutions and the dual character of their variability through time. The social evolution and the fundamental changes in the society lead to "decay and obstruction of institutions which in their day were essential to progress" (Commons, 1896 , p. 10). On the one hand, alike biological world or in primitive times, the institutions can be the subject and the result of a certain influence of natural selection when "those individuals survive and prosper who are best able to utilize the passions, customs, and legal regulations of their fellowme" (Commons, 1896, p. 166) Just from positions of natural selection John R. Commons also considered the process of monopolization when due competition weak competitive side is crushed out, the number of competitors becomes smaller and finally one is left (Commons, 1921, p. 61). On the other hand, unlike the biological changes, society can change its customs and laws within certain limitations and thereby give the institutions new capabilities which are necessary for a certain time. In other words, John R. Commons recognized the deliberate adaptability of institutions to the modern time.

In 1924 John R. Commons developed the understanding of institutions as rules (Commons 1924). Before Commons this idea was expressed by an American jurist Wesley Newcomb Hohfeld (1879-1918) in his "Some Fundamental Legal Concepts as Applied in the Study of Primitive Law" (Hohfeld 1913). The concept of "institutions as the rules" is based on the presentation that institutions and humans exist separately from each other and institutions represent the rules of the game, rather than specific players. Just these positions and such understanding were developed later by North.

Slightly before John R. Commons, an American economist and professor of law Walton H. Hamilton (1881-1958) expressed more assuredly the interdependence of institutions and behavior. Defining the term institution in 1919 he wrote: "Institutions, seemingly such rigid and material things, are merely conventional methods of behavior on the part of various groups or of parsons in various situations. The changes which processes reveal are merely changes in human actions. It is necessary, therefore, that economic theory should proceed from an acceptable theory of human conduct" (Hamilton, 1919, p. 316). Inasmuch, for Walton Hamilton "economic theory must be based upon an acceptable theory of human behavior" (Hamilton, 1919, p. 316), therefore in his understanding the institutional economics most accurately corresponds to goals and aims of economic theory. 
Criticizing the approach of old economic theory toward the human economic behavior, Walton Hamilton mentioned a neglecting of influence "exercised over conduct by the scheme of institutions under which one lives and must seek his good" as a more essential blunders of old classical school of economics.

Walton Hamilton developed the outline of the arguments in support of the institutional theory. He recognized that institutional economics is in a constant process, in constant motion and opposes the achievements of the neoclassical theory. Walton Hamilton formulated some directions for future development of institutional economics for its further progress. Continuing the tradition of Veblen, Walton Hamilton denominated the qualities of human nature such as instinct, impulse, etc. as one of more important roots of human activity which have to be studied by institutional economics. As the next goal of the future development of institutional economics Walton Hamilton also mentioned the necessity to identify the variety of institutional situations as a chief source of differences in the context of human behavior. Along with that, institutional economics must take into account the limitations imposed by past activities upon the flexibility with which a given individual may act in the future (Hamilton, 1919, p. 317).

\section{Conclusions}

The attitude towards institutions initially was not homogeneous. It refers to the earliest period of usage of the term of institutions by religious figures such as Saint (Venerable) Bede and Thomas Aquinas, as well as to relatively later period of applying the notion of institutions by Thomas Hobbes, Giambattista Vico, by representatives of classical political economy in particular David Hume and Adam Smith, as well as by the followers of classical liberal political theory Herbert Spencer. Such position was also continued by subsequent generations of thinkers including German Historical School.

Beginning from the earliest years of the institutional understanding of economic theory as well as in previous periods many types of institutions were mentioned. Such a variety of institutions, as it was mentioned by Walton H. Hamilton, could be explained due to the diversity of economic problems which have to be resolved. Protecting the institutionalism and institutional methods of investigations and explaining the multiplicity of institutions, Walton H. Hamilton mentioned that "a control of particular aspects of economic life requires knowledge of particular institutions" (Hamilton, 1919 , p. 313). 
From the beginning of the early stages of its existence, the concept "institution" was tightly associated with regulations of human and collective action, with behavior of men and organizations. The uncertainty of the concept of "institution" proceeds from the versatility and variety of institutions themselves, their occurrence in all spheres of life - political, social, economic, by complexity of separation of the object which determine the directions and conditions of action (behavior) from these directions and conditions themselves. Namely, in such context institutions can be perceived as something elusive, intangible and look like "the grin without cat" (Furubotn \& Richter, 2007, p. 7).

But from the beginning of their existence and in spite of multiplicity, plurality of their essence, understanding institutions has always meant the necessity to comply with certain conventionalities by certain subjects i.e. the notion "institution" has always implied conditions of actions, as well as the subjects of actions or rules and players.

\section{References}

Arrow, K. (1974). The Limits of Organization. New York: Norton.

Aquinas, T. (1256). Summa Theologica, vol. 1. Retrieved form http://oll.libertyfund.org/titles/aquinas-the-summa-theologica-of-st-thomasaquinas-part-i-qq-i-xxvi-vol-1 (14.07.2014).

Aquinas, T. (1274). Aquinas Ethicus: or, the Moral Teaching of St. Thomas, vol. 2. Bede Saint (1916). The Eccesiastical History of the English Nation (and Lives of Saints and Bishops). London \& Toronto: J. M.Dent\&Sons.

Bucher, C. (1901). Industrial Evolution. Original Published United States. Commons, R. J. (1893). The Distribution of Wealth. New York: Macmillan.

Commons, R. J. (1894). Social Reform and the Church. New York: Thomas Y. Crowell.

Commons, R. J. (1896). Proportional Representation. New York: Crowell.

Commons, R. J. (1907). Races and Immigrants in America. New York: Macmillan. Commons, R. J. (1921). Trade Unionism and Labor Problems. Boston: Ginn and Co.

Commons R. J. (1924). Legal Foundations of Capitalism. New York: Macmillan. Commons R. J. (1931). Institutional Economics. American Economic Review, 21.

Furubotn, E. G. \& Richter, R. (2007). Institutions and Economic Theory: The Contribution of the New Institutional Economics. Michigan.

Hamilton, D. (1962). Why Is Institutional Economics Not Institutional?. American Journal of Economics and Sociology, 21(3).

Hamilton, W. H. (1919). The Institutional Approach to Economic Theory. American Economic Review, 9(1).

Harris, A. L. (1932). Types of Institutionalism. Journal of Political Economy, 4(6). Hawtrey, R. (1925). Review of Knapp's The Theory of Money. Economic Journal, 35. 
Hohfeld, O. N. (1913). Some Fundamental Legal Concepts as Applied in the Study of Primitive Law. Yale Law Journal, 23.

Hodgson, M. G. (1998). On the evolution of Thorstein Veblen's evolutionary economics. Cambridge Journal of Economics, 22.

Hodgson, M. G. (2003). John R. Commons and the Foundations of Institutional Economics. Journal of Economic Issues, 37(3).

Hodgson, M. G. (2006). What Are Institutions?. Journal of Economic Issues, 40(1).

Hollingsworth, J. R. (2000). Doing Institutional Analysis: implications for the study of innovations. Review of International Political Economy, 7(4).

Hobbes, T. (1660). The Leviathan. Retrieved form http://oregonstate.edu/instruc t/phl302/texts/hobbes/leviathan-contents.html (14.07.2014).

Hume, D. (1739). A Treatise of Human Nature, Reprinted from the Original Edition in three volumes and edited, with an analytical index, by L.A. Selby-Bigge. Oxford: Clarendon Press (1896). Retrieved form http://oll.libertyfund.org (14.07.2014).

List, F. (1909). The National System of Political Economy. London: Longmans, Green\&Co.

Leftwich, A. (2006). What are Institutions? IPPG Briefing Paper no. one, IDPM, School of Environment \& Development University of Manchester.

Knapp, G. F. (1924). The State Theory of Money. London: Masmillan \& Company Limited.

Marshall, A. (2000). Principles of Economics. London: Macmillan and Co.

Rutherford, M. (1983). J. R.Commons's Institutional Economics. Journal of Economic Issues, 17(3).

Rutherford, M. (2001). Institutional Economics: Then and Now. Journal of Economic Perspectives, 15(3).

Rutherford, M. (2008). Institutionalism Between the Wars. Retrieved form http://www.univie.ac.at/strv-vwl/wp/wp-content/uploads/2011/11/institutiona lism_between_the_wars.pdf (14.06.2014).

Searle, J. R. (2005). What is an Institution?. Journal of Institutional Economics, $1(1)$.

Smith, A. (1843). An Inquiry Into the Nature and Causes of the Wealth of Nations. Edinburgh: Thomas Nelson.

Sombart, W. (1909). Socialism and the Social Movement. London: J.M.Dent \& CO, New York: E.P.Dutton \& CO MCMIX.

Sombart, W (2001). The Jews and Modern Capitalism. Ontario: Batoche Books Limtied.

Spencer, H. (1898). The Principles of Sociology, 3 vols. Retrieved form http://oll.libertyfund.org/titles/spencer-the-principles-of-sociology-3-vols-1898 (24.06.2014).

Spencer, H. (1891). Essays: Scientific, Political and Speculative, 3 vols. Retrieved form http://oll.libertyfund.org/titles/spencer-essays-scientific-political-andspeculative-vol-1--5 (7.07.2014).

Schmoller, G. (1881). The Idea of Justice in Political Economy. Annals of the American Academy of Political and Social Science, 4. Retrieved form http://socserv2.mcmaster.ca/econ/ugcm/3113/schmoller/justice (7.07.2014). 
Schmoller, G. (1900). Grundriß der Allgemeinen Volkswirtschaftslehre. Leipzig: Erster Teil, Duncker\&Humblot.

Schmoller, G. (1911), Volkswirtschaft, Volkswirtschaftlehre und methode. In: J. Conrad, L. Elster, W. Lexis, \& E. Loening (Eeds.). Handworterbuch der Staatswissenschaften, Vol. 8. Jena: Gustav Fischer.

Schumpeter, J. A. (1926). Gustav v. Schmoller und die Probleme von heute, Schmollers Jahrbuch für Gesetzgebung. Verwaltung und Volkswirtschaft, 50.

The Historicity of Economics: Continuities and Discontinuities of Historical Thought in 19th and 20th Century Economics (2002), H. N. Heinoh \& B. Schefold, Berlin: Springer-Verlag.

Veblen, T. (1898). Why is Economics Not an Evolutionary Science. Quarterly Journal of Economics, 12.

Veblen, T. (1899). The Theory of the Leisure Class: An Economic Study of Institutions. New York: The Macmillan Company.

Veblen, T. (1917). An Inquiry into the Nature of Peace and the Terms of its Perpetuation. New York: The Macmillan Company.

Veblen, T. (2001). The Engineers and the Price System. Ontario: Batoche Books, Kitchener.

Veblen, T. (1904). The Theory of Business Enterprise. New York: Charles Scribner's Sons.

Vico, G. (1948). The New Science, New York: Cornell University Press, ITHACA. Retrieved form https://ia600302.us. archive.org/23/items/newscienceofgiam030 174mbp/newscienceofgiam030174mbp.pdf (4.08.2014).

Williamson, O. E. (2000). The New Institutional Economics: Taking Stock, Looking Ahead. Journal of Economic Literature, 38(3). 